\title{
Leadership according to God's model: Is it possible to use the Bible to define God's leadership?
}

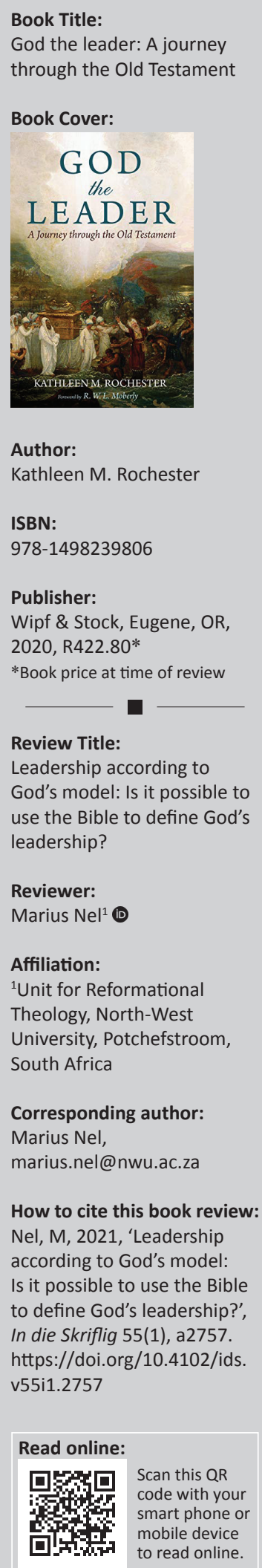

Author:

Kathleen M. Rochester

ISBN:

978-1498239806

Publisher:

Wipf \& Stock, Eugene, OR, 2020, R422.80*

*Book price at time of review

Review Title:

Leadership according to God's model: Is it possible to use the Bible to define God's leadership?

Reviewer:

Marius $\mathrm{Nel}^{1}$

\section{Affiliation:}

${ }^{1}$ Unit for Reformational Theology, North-West University, Potchefstroom, South Africa

Corresponding author: Marius Nel, marius.nel@nwu.ac.za

How to cite this book review: $\mathrm{Nel}, \mathrm{M}, 2021$, 'Leadership according to God's model: Is it possible to use the Bible to define God's leadership?', In die Skriflig 55(1), a2757. https://doi.org/10.4102/ids. v55i1.2757

Read online: code with your smart phone or mobile device to read online.

Each year we see many new works about leadership, also from theological perspectives. To make an original contribution is understandably tricky. This particular author approaches the subject from another angle: readers' ideas about God's leadership that subconsciously shape their own ideals and priorities in leadership. Rochester intends to investigate the effect that questions about God's character and leadership have on the way believers define leadership.

To accomplish that, she revisits the 'bad' leadership models and replaces them with the 'model of the leadership of the person of God'. She argues that leaders will benefit if they continue to acknowledge God as leader, because it will allow us to imitate God's leadership model.

Further, she limits her investigation to include the Old Testament only. Her presupposition is clear, namely that it is possible to delineate the 'model of God's leadership' based on available biblical data. She asserts that the Old Testament's God is often painted very differently from the New Testament's God. The implication is that the representation in the various literary genres from different historical eras, based on diverse ideological ideas found in the Old Testament, provides only one clear picture.

In discussing God's leadership, a summary of the early days of Israelite history that ends with the Torah being given at Mount Sinai, using the experiences of the people portrayed in the Exodus narrative to generalise about God's leadership. For the author, it is essential to note that God the leader, chooses the mode of leadership most needed for the people at a particular time. At times, God's leadership seems hidden, perhaps silent or, at least, perplexing. At other times, the leadership model might be that of a commanding, influential and provisioning presence. In a subsequent section, the Ten Commandments are discussed, presupposing that they are not to be confined by narrowly legalistic interpretations, but taken as umbrella principles that include or refer to a wide range of related issues. The purpose of the discussion is to show that God as leader acts to advance salvation and liberation of God's people, so that they may walk in freedom and away from slavery, because God understands human weaknesses. According to Rochester, the Ten Commandments operate in the context of Israel's already established and covenanted relationship with God. By setting boundaries, God acts in interest of the community's well-being, and for that reason, condemns divisive behaviour and the violation of other people's rights. The instructions were flexible enough to allow variations in particular cases. Furthermore, because God is fair, the promised punishments fit the crimes.

In the next section, Rochester discusses God's leadership regarding ethnicities and other separations between insiders and outsiders, as well as issues such as land and war, that are fraught with difficulties for political leaders, and with implications for many other non-political groups. Then several biblical instances are described of God's leadership, and developed for their practical application. Interesting is the author's discussion of God as a father, mother and husband. Finally, the latter part of Israel's history is discussed, as to their response of disobedience, punishment, exile, and resettlement. Also the influence of prophets from a pre-eschatological perspective, provides a glimpse of the new hope found in the coming of the promised Messiah.

The work concludes that God's leadership is characterised by flexibility, the hallmark of God's leadership, and it is applicable to new situations and needs. Because God's leadership is never merely mechanical, Rochester argues readers should continue reading it and reflecting on it, and continue the conversation with God to sharpen their leadership skills.

The book is not an academic or scholarly work, but instead utilises the personal experiences of the author and other figures in literature to open a biblical discussion of leadership, as found

Copyright: @ 2021. The Authors. Licensee: AOSIS. This work is licensed under the Creative Commons Attribution License. 
in the Old Testament and applied to God. Readership should include believing Christians and their leaders, who may benefit from the discussions. The standard of the work is suitable for that; it does not include specialised exegetical discussion of biblical passages, or the different opinion that many scholars hold about biblical texts' various issues. The last remark is that the discussion of biblical events to deduce principles and examples from God's leadership, seemed to be forced and was not always convincing. It seems that the author came to irrelevant conclusions about certain texts, with the implication that the reader is not really convinced that the Bible can, in fact, be used to define a model of God's leadership, compared to current leadership models. 